\title{
1603: Multiple Monarchy and Scottish Identity
}

\author{
ROGER A. MASON \\ University of St Andrews
}

\begin{abstract}
Early modern geopolitics were largely driven by dynastic imperatives - births, marriages and deaths among Europe's royal families - and this article approaches the union of 1603 from the perspective of J. H. Elliott's A Europe of Composite Monarchies. Thus, it explores how Scots perceived their place within this new dynastic empire and the hopes and fears their new relationship with England engendered. It begins, however, by examining the baptism in 1594 of James VI's son and heir, Prince Henry, and the clear dynastic message that the Scottish king was sending to his future English subjects. It then turns to the ways in which the Scots sought to celebrate the king's accession to the English and Irish thrones in 1603, ways that deliberately legitimised their belief that the union should be perceived as one of equals. It then examines four tracts written at the time of the union by the Scottish lawyer and legal scholar Thomas Craig of Riccarton that reveal both the aspirations and anxieties that the union generated in Scotland. Overall, it argues that Scots were both deeply sceptical of the king's plans for 'complete' union and deeply hostile to prevailing English assumptions of superiority. Rather they saw it as a union of equals with profound implications for the future stability of the new Stewart imperium.
\end{abstract}

It has been persuasively argued that James VI of Scotland's accession to the thrones of England and Ireland in 1603 was by no means as smooth a transition as historians have often assumed. ${ }^{1}$ The Conference about the Next Succession to the Crowne of England, written by the English Jesuit Robert Parsons and published in Antwerp in 1595, proved particularly unsettling, not least for James himself, in openly advocating elective over hereditary monarchy and challenging his right to succeed. The king's own political writings, notably his The True Law of Free Monarchies (1598), in arguing forcefully for the principle of indefeasible hereditary right, were both a response to this threat and a measure of the

\footnotetext{
${ }^{1}$ See e.g. Susan Doran, 'James VI and the English succession', in Ralph Houlbrooke (ed.), James VI and I: Ideas, Authority, and Government (Aldershot, 2006), pp. 25-42, and the essays, especially those by the editors, in Susan Doran and Paulina Kewes (eds), Doubtful and Dangerous: The Question of Succession in Late Elizabethan England (Manchester, 2014).
} 
king's heightened anxiety. ${ }^{2}$ Nonetheless, contemporary rules of heredity prevailed, and James Stewart, king of Scotland, duly succeeded Elizabeth Tudor unopposed to the thrones of England and Ireland. Indeed, the change of monarch was not only accomplished peacefully, but for the majority of the inhabitants of those three kingdoms made no difference at all. It was only their ruling elites who had anything to gain or lose from such new arrangements as arose from the kind of dynastic union that was part-and-parcel of contemporary politics and diplomacy.

Thanks largely to J. H. Elliott, we are all now familiar with the idea of a composite monarchy, exemplified by the Habsburg's sprawling domains, but equally by contiguous territories such as Poland-Lithuania or close neighbours such as Denmark-Norway. ${ }^{3}$ The sixteenth-century English monarchy was already a composite one in that it also ruled over the kingdom of Ireland and the principality of Wales, while having dominion over off-shore islands with distinctive jurisdictions (e.g. Jersey and Guernsey) as well as embryonic transatlantic colonies. In this perspective, the union of 1603 saw the entrance onto the early modern European stage of a new but by no means unusual dynastic conglomerate that brought together under a single Stewart ruler the various island kingdoms and communities of the Atlantic Archipelago. ${ }^{4}$

Within this conglomerate, however, the constitutional relationship between Scotland and England proved particularly contentious: while the English crown had long claimed lordship over the Scottish kingdom, Stewart monarchs, and their subjects, saw themselves as emphatically independent, glorying in a long history of what they considered a 'free' and 'imperial' monarchy. ${ }^{5}$ This partly accounts for the different ways in which the union was perceived in the two kingdoms and, here again, Elliott is a useful guide to how contemporaries might have construed it. In his seminal essay on composite monarchies, he cited the seventeenthcentury Spanish jurist Juan de Solarzano Pereira, distinguishing between two kinds of union. The first was what he called an 'accessory' union, whereby one territory was simply incorporated into and ruled in the same way as another territory, subject to its government and its laws. We might

\footnotetext{
${ }^{2}$ Peter Lake, 'The king (the queen) and the Jesuit: James Stuart's True Law of Free Monarchies in context/s', Transactions of the Royal Historical Society, 6th ser., 14 (2004), pp. 243-60. In James's view, the claim of blood obviously also overrode domestic English objections based on statute law or Henry VIII's will. These issues are discussed more fully in Rei Kanemura, 'Kingship by descent or kingship by election? The contested title of James VI and I', Journal of British Studies, 52 (2013), $317-42$.

3 J. H. Elliott, 'A Europe of composite monarchies', Past \& Present, 137 (1992), pp. 48-71.

${ }^{4}$ For a recent take on Britain as a 'dynastic agglomeration', see John Morrill, "'Uneasy lies the head that wears a crown": dynastic crises in Tudor and Stewart Britain, 1504-1746', Stenton Lecture, University of Reading (Reading, 2005); and in updated form: 'Dynasties, realms, peoples and state formation, 1500-1720', in John Morrill and Robert Friedeburg (eds), Monarchy Transformed: Princes and their Elites in Early Modern Western Europe (Cambridge, 2017), pp. 17-43.

${ }^{5}$ See Roger A. Mason, 'This realm of Scotland is an empire? Imperial ideas and iconography in early Renaissance Scotland', in Barbara Crawford (ed.), Church, Chronicle and Learning in Medieval and Early Renaissance Scotland (Edinburgh, 1999), pp. 73-91.
} 
prefer the term 'incorporating' to 'accessory' and we might also follow Elliott in pointing to the incorporation of Wales into a greater English state as an example of this. ${ }^{6}$ However, Solarzano identified another form of union, one that was perhaps more typical of early modern composite monarchies, which he described in a Latin phrase as a union aeque principaliter, that is, a union in which the parties were, literally, 'equally important', within which they were accorded parity of status and esteem, and within which they continued to be governed according to their own customs and traditions, their own 'laws and liberties'. ${ }^{7}$ As Jenny Wormald memorably put it, in this sort of composite or multiple monarchy, the ruler was certainly king of all, but he was also king of each, bound to respect the integrity and identity of the individual components of his imperium. ${ }^{8}$

Wormald is one of the few historians to have framed the union of 1603 in terms of composite monarchy and to have explored how it was perceived by contemporaries in its immediate aftermath. ${ }^{9}$ While there is a substantial body of scholarship focused on Jacobean debates on the idea of Britain - the seminal work of Bruce Galloway and Brian Levack, for example, and a range of thought-provoking publications by Arthur Williamson - there remains scope for further investigation of how the union was perceived in Scotland that takes Elliott's model, and Solarzano's taxonomy of union, as its starting point. ${ }^{10}$ With this in mind, there is a distinction to be made between an English political establishment that tended to view the union as an incorporating one and a Scottish insistence that it was a union aeque principaliter, a union of equals that accorded parity of status and esteem to each partner in

\footnotetext{
${ }^{6}$ The idea of an accessory union presumably derives from the legal maxim, originating in classical Roman property law, accessorium sequitur naturam sui principalis ('the accessory follows the nature of the principal'), which is the first entry in contemporary alphabetical legal compendia known as Brocardica Iuris, frequently reprinted in the sixteenth century and beyond.

7 Elliott, 'Composite monarchies', pp. 52-3. For its application in relation to the union of Poland and Lithuania, see Robert I. Frost, The Oxford History of Poland-Lithuania, I: The Making of the Polish-Lithuanian Union, 1385-1569 (Oxford, 2015), ch. 33.

8 Jenny Wormald, 'The creation of Britain: multiple kingdoms or core and colonies?', Transactions of the Royal Historical Society, 6th ser., 2 (1992), pp. 175-94; see also Jenny Wormald, 'The Union of 1603', in Roger A. Mason (ed.), Scots and Britons: Scottish Political Thought and the Union of 1603 (Cambridge, 1994), pp. 17-40, esp. pp. 32-3.

9 An important exception to this is the discussion of union in Conrad Russell, King James VI and I and his English Parliaments, ed. Richard Cust and Andrew Thrush (Oxford, 2011), pp. 123-39. Elsewhere the idea of multiple monarchy is more often used to explain its implosion in the 1630s and 1640s; see e.g. Keith Brown, 'A blessed union? Anglo-Scottish relations before the covenant', in T. C. Smout (ed.), Anglo-Scottish Relations from 1603 to 1900 (Oxford, 2005), pp. 37-55; and Conrad Russell, 'Composite monarchies in early modern Europe: the British and Irish example', in Alexander Grant and Keith Stringer (eds), Uniting the Kingdom? The Making of British History (London and New York, 1995), pp. 133-46.

10 Bruce Galloway, The Union of England and Scotland, 1603-1608 (Edinburgh, 1986); Brian P. Levack, The Formation of the British State: England, Scotland and the Union, 1603-1707 (Oxford, 1987); for a recent example of Arthur Williamson's work on this theme, see his 'David Hume, Richard Verstegan, and the Battle for Britain', in R. Malcolm Smuts (ed.), The Oxford Handbook of the Age of Shakespeare (Oxford, 2016), pp. 322-45; but see also the introduction to Paul J. McGinnis and Arthur H. Williamson (eds), The British Union: A Critical Edition and Translation of David Hume of Godscroft's 'De Unione Insulae Britannicae' (Aldershot, 2002).
} 
the arrangement. Yet, while the Scots' reluctance to be 'accessorised' is straightforward enough, there are nuances to how the transition was perceived in the years either side of 1603 that are worth teasing out. There is no doubt, for example, that the king's own promotion of a British agenda, his persistent talk of an ill-defined 'perfect' union, complicated understandings of how multiple monarchy might function in practice, while ignoring pronounced ambiguities inherent in British terminology. It is also the case that contemporaries were well aware of the disparities in population, wealth and resources between the two kingdoms and that this posed acute, and ultimately unresolvable, problems for seventeenthcentury Stewart monarchs in their efforts to manage a union of unequal equals. ${ }^{11}$ Here, however, in the central section of what follows attention is focused on how English assumptions of superiority, political and cultural as well as economic, were countered by Scots in ways that legitimised their insistence that their kingdom be treated aeque principaliter. Using a range of little-known printed pamphlet material, this article shows how the Scottish intelligentsia, while embracing union, sought to promote Scottish distinctiveness within it. Among the contributors to this literature was Thomas Craig of Riccarton, the noted Scottish jurist who also sat on the king's union commission and whose treatise, De Unione Regnorum Britanniae (1605), although unpublished at the time, is well known to historians. Less well known are two other lengthy tracts that Craig wrote in the years either side of 1603 that also bear on the issue of union. In the final section of what follows, these writings are considered together in ways that illuminate how Craig, perhaps like many Scots, sought to steer a course between his own native pride and what he clearly considered intolerable English prejudice. At the same time, they may help unpack the king's own understanding of what 'perfect' union entailed. As a prelude, however, it is worth considering what was a moment of intense, though under-appreciated, dynastic significance: the birth of James VI's first child, Prince Henry Frederick, on 19 February 1594 and his baptism six months later on 30 August. For in laying on a lavish and vastly expensive baptismal celebration, the Scottish king indubitably had uppermost in his mind what he considered his imminent English succession.

\section{II}

In February 1594 Elizabeth Tudor was unmarried, childless and sixty years old. She was in fact the first and only Tudor ruler to achieve sexagenarian status: her half-brother Edward VI had died before reaching his sixteenth birthday, while her grandfather Henry VII had died aged fifty-two, her father Henry VIII aged fifty-five, and her half-sister Mary

\footnotetext{
11 The literature on this is vast, but for an overview from the perspective adopted here, see Roger A. Mason, 'Debating Britain in seventeenth-century Scotland: multiple monarchy and Scottish sovereignty', Journal of Scottish Historical Studies, 35 (2015), pp. 1-24.
} 
aged forty-two. ${ }^{12}$ No self-respecting actuary would have predicted that Elizabeth would defy her family genes and live for the best part of another decade. Certainly, her cousin James VI of Scotland, descended from Elizabeth's aunt, Henry VIII's sister, Margaret, did not anticipate such a long and nervous wait for what he had long regarded as his rightful inheritance. In February 1594, James was twenty-seven, a young but already highly experienced monarch who, after a very troubled minority, was intent on asserting real control over his kingdom. ${ }^{13} \mathrm{He}$ was also married. Famously, in 1589-90, he had voyaged in person to DenmarkNorway to wed the fifteen-year-old Anne, the younger daughter of Frederick II. In a world of dynastic contingencies, where births, marriages and deaths were the essence of diplomacy, a Stewart-Oldenburg alliance was not only prestigious for James, but made sound religious as well as commercial sense. ${ }^{14}$ The subsequent birth of a male heir, moreover, and the promise of a secure succession, was a priceless diplomatic asset that James was determined to exploit for all it was worth.

It was not unusual for royal baptisms to be accompanied by extravagant celebrations. In December 1566 the infant James had himself been at the heart of a spectacular baptismal festival at Stirling Castle that his mother had laid on with the clear purpose of proclaiming and promoting the Stewarts' place in the English succession. ${ }^{15}$ Almost three decades later, with one eye still firmly fixed on the English throne, and once again against the impressive backdrop of Stirling Castle, the arrangements made by James for his son's christening were similarly spectacular. ${ }^{16}$ We

${ }^{12}$ For these details, see E. B. Fryde et al. (eds), Handbook of British Chronology, 3rd edn (London, 1986), pp. 42-3.

${ }_{13}$ Although this domestic context cannot be pursued here, the baptism took place against a backdrop of political disorder involving inter alia the rebellious activities of the earl of Bothwell and the Catholic earls that the king was no doubt keen to minimise. On these events, which came to a head in 1596, see Julian Goodare, 'Scottish politics in the reign of James VI', in Julian Goodare and Michael Lynch (eds), The Reign of James VI (East Linton, 2000), pp. 32-54, and Julian Goodare, 'The attempted Scottish coup of 1596', in Julian Goodare and Alasdair MacDonald (eds), SixteenthCentury Scotland: Essays in Honour of Michael Lynch (Leiden, 2008), pp. 311-36. The expense and problematic logistics of the baptism are considered in Amy L. Juhala, 'The household and court of King James VI of Scotland, 1567-1603' (unpublished PhD thesis, University of Edinburgh, 2000), pp. 211-17.

${ }_{14}$ David Stevenson, Scotland's Last Royal Wedding: The Marriage of James VI and Anne of Denmark (Edinburgh, 1997); Steve Murdoch, Britain, Denmark-Norway and the House of Stuart, 1603-1660 (East Linton, 2003), esp. ch. 1.

${ }_{15}$ Michael Lynch, 'Queen Mary's triumph: the baptismal celebrations at Stirling in December 1566', Scottish Historical Review, 69 (1990), pp. 1-21. While James's baptism was a Catholic one, his son's was of course Protestant.

${ }^{16}$ For commentary on the event, see Michael Lynch, 'Court ceremony and ritual during the personal reign of James VI', in Lynch and Goodare (eds), Reign of James VI, pp. 71-92; Michael Lynch, 'The reassertion of princely power in Scotland: the reigns of Mary Queen of Scots and James VI', in M. Gosman et al. (eds), Princes and Princely Culture, 1450-1650 (Leiden, 2003), pp. 199-238; Clare McManus, 'Marriage and the performance of the romance quest: Anne of Denmark and the Stirling baptismal celebrations for Prince Henry', in L. Houwen et al. (eds), A Palace in the Wild: Essays on Vernacular Humanism in Late Medieval and Renaissance Scotland (Louvain, 2000), pp. 175-98; Rick Bowers, 'James VI, Prince Henry and a True Reportarie of the baptism at Stirling 1594', Renaissance and Reformation, 29 (2005), pp. 3-22; Michael Bath, "'Rare shewes and singular 
are fortunate, moreover, that the king took the trouble to ensure that a detailed account of the proceedings was published in its immediate aftermath. Titled The True Reportarie ... of the Baptisme, it was written by William Fowler, Queen Anne's secretary and an accomplished man of letters, who was also a key member of the team responsible for choreographing the celebrations. ${ }^{17}$ These involved elaborate chivalric games on the day preceding the baptism, featuring among other 'Martiall and heroicall exploites' the unlikely sight of three Scottish nobles riding at the ring cross-dressed as Amazons. ${ }^{18}$ Less surprising, not least in the light of what became typical behaviour for James, was the lavish banquet that was held after the ceremony. It began at eight in the evening and concluded at three in the morning. Its highlight was undoubtedly the trundling into the Great Hall of a 'singular device' in the form of a model ship, its keel eighteen feet long, its masts forty feet tall, its sails emblazoned with the arms of Denmark and Scotland, and the whole clearly intended - as Fowler explained - to recall the king's voyage to claim his bride. Encrusted with pearls, corals and shells, manned by Neptune, Triton and half a dozen mariners, the ship came equipped with ordnance that was discharged to announce both its arrival and its departure. Its cargo was the fish course: herring, whiting, flooks, oysters, buckies, limpets, partans, lobsters, crabs, spout-fish and clams, "with other infinit things made of Suger, and most viuely represented in their owne shape'. ${ }^{19}$ As this suggests, and the rest of Fowler's account makes clear, no expense was spared in mounting these spectacles. Another of the complex devices that enlivened the banquet was an enormous chariot, twelve feet long, that the king had hoped would be drawn into the hall by his pet lion, but that in the interests of health and safety was dragged instead by a 'Black Moore'. The chariot bore a table laden with 'exquisite delicacies and dainties', but in more serious vein featured six female figures representing Ceres and Fecundity, symbols of fertility, as well as the princely virtues Faith, Concord, Liberality and Perseverance. ${ }^{20}$

\footnotetext{
inventions": the Stirling baptism of Prince Henry', Journal of the Northern Renaissance, 4 (2012), paras 1-20; and Richard Hillman, 'God-fathering Prince Henry', in J.-C. Mayer (ed.), The Struggle for the Succession in Late Elizabethan England (Montpellier, 2004), pp. 313-26.

${ }_{17}$ A True Reportarie of the Most Triumphant, and Royal Accomplishment of the Baptisme of the Most Excellent, Right High, and Mightie Prince, Frederick Henry (Edinburgh, 1594). This edition, used in what follows, was issued by the king's printer, Robert Waldegrave, see A. W. Pollard et al. (eds), A Short-Title Catalogue of Books Printed in England, Scotland and Ireland and of English Books Printed Abroad 1475-1640, 2nd edn (3 vols; London, 1976-91), no. 12146 [hereafter STC]; another was printed in London by Peter Short (STC 112147). The Reportarie is also printed in H. W. Meikle et al. (eds), The Works of William Fowler, Secretary to Queen Anne, Wife of James VI, Scottish Text Society (3 vols; Edinburgh and London, 1914-40), III, pp. 165-95. For recent reappraisals of Fowler's poetry and prose, including his translation of Machiavelli's Prince, see Sebastiaan Verweij, The Literary Culture of Early Modern Scotland: Manuscript Production and Transmission, 1560-1625 (Oxford, 2016), ch. 3, and Alessandra Petrina (ed.), Machiavelli in the British Isles: Two Early Modern Translations of The Prince (Farnham, 2009).

${ }_{18}$ Reportarie, sig. A4r-v.

19 Ibid., sig. C4r-D1v.

${ }^{20}$ Ibid., sig. C3r-C4r.
} 
Amidst all the jollity and pageantry, and summed up by the solemn baptismal ceremony itself, a deeply serious political point was being made: James had a male heir and not only was the Scottish succession secure, but so too, potentially, was that of England. The latter point is never made explicit in the spectacle, but the whole event was deliberately geared towards English consumption. There was nothing coincidental about Fowler's Reportarie being published simultaneously in London as well as Edinburgh. ${ }^{21}$ Moreover, the six-month delay between birth and baptism did not occur because James needed to build a new chapel royal at Stirling, although he did take the opportunity to spend lavishly on its construction. ${ }^{22}$ Rather, it was a delay caused primarily by anxiety to ensure the presence of Elizabeth's representative at the baptism. This was originally to be George Clifford, the buccaneering third earl of Cumberland, but ill-health prevented him attending, and it was the young Robert Radcliffe, fifth earl of Sussex, who eventually stood in for Elizabeth, the infant prince's godmother, just as she had been for James himself in $1566 .{ }^{23}$ The delay annoyed the Danish, German and Dutch ambassadors, who after weeks of waiting were keen to get home before autumn weather set in, but James was determined that the baptism of his heir be acknowledged and celebrated by the crown of England. At the christening itself, the seat of honour immediately to the king's right was rather theatrically left empty as the French representative failed to turn up, but Sussex was entrusted with carrying the prince into the chapel royal for the ceremony and was seated at the king's right hand for the banquet. ${ }^{24}$

The christening has been described as 'gorgeously Episcopal' and its 'high church pageantry and finery' seen as a nod towards the English church and a post-union royal ecclesiastical policy of Anglicisation. ${ }^{25}$ There is some truth in this in that the new pulpit in the chapel royal was 'richly hung with cloth of gold' and that David Cunningham, bishop of Aberdeen, took part in what was a carefully choreographed ceremony that also involved two other moderate-minded ministers, the king's longserving personal chaplain, John Duncanson, and David Lindsay, minister of Leith, who had conducted the marriage of James and Anne in 1589 and who would subsequently be appointed bishop of Ross. Yet, despite James's ongoing efforts to establish episcopacy in Scotland, too much

\footnotetext{
21 See n. 17 above.

22 See Ian Campbell and Aonghus Mackechnie, 'The "Great Temple of Solomon" at Stirling', Architectural History, 54 (2001), pp. 91-118.

23 Reportarie, sig. A3r-v. Cumberland had served on the commission that 'tried' Mary Queen of Scots in 1586 and was present at her execution the following year. That he was replaced by Sussex may have saved some embarrassment; see V. Stater, 'Radcliffe, Robert, fifth earl of Sussex (1573-1629), soldier and courtier', Oxford Dictionary of National Biography, accessed 5 Jan. 2020; P. Holmes, 'Clifford, George, third earl of Cumberland (1558-1605), courtier and privateer', Oxford Dictionary of National Biography [accessed 5 Jan. 2020].

24 Reportarie, sigs B2r, B3r, C2v. Robert Bowes, the resident English ambassador in Edinburgh, also attended the various events associated with the baptism.

25 Bowers, 'James VI, Prince Henry and a True Reportarie', pp. 11-13.
} 
should not be made of the 'high church' nature of the ceremony. ${ }^{26}$ After all, cloth of gold or no, the pulpit remained at the heart of the proceedings, proceedings that began with a sermon on Genesis 21 by another of the king's chaplains, Patrick Galloway, and an oration by Cunningham (first in Scots and then in Latin) explaining the sacrament of baptism. There then followed the singing of Psalm 21, 'according to the Art of Musique', which may imply a choir of trained singers (Fowler refers to 'the Provost and Prebends of the Chapel Royal'), but hardly seems to warrant the 'high church' label. Fowler says nothing of the content of Cunningham's oration, but the baptism itself appears to have been restricted to the bare minimum of water and the Trinitarian formula: the prince was named, Fowler tells us, 'and so Baptized, in the name of the Father, Sonne and holy Ghost'. ${ }^{27}$ The elaborately sequenced pageantry of the processions in and out of the chapel was impressively lavish, with Sussex playing a key role, striding babe-in-arms under a velvet canopy held aloft by four Scottish lairds, led by the king's heralds and accompanied by the sound of trumpets. ${ }^{28}$ Overall, however, the proceedings appear calculatedly inclusive, as inoffensive to the king's foreign guests as they were to his Scottish subjects. ${ }^{29}$

These even included, or so it would seem, his Presbyterian subjects. Fowler's account of the baptism never mentions the English succession, although it is impossible to read it without Elizabeth's age and James's prospects coming immediately to mind. However, at least one other work, also published in Edinburgh in 1594 by the king's printer Robert Waldegrave, was much less coy in spelling out the significance of Prince Henry's birth and baptism. This was a Latin poem of some ninety lines entitled Principis Scoti-Britannorum Natalia by none other than the Presbyterian cleric Andrew Melville. Conventional wisdom would have James and Melville perpetually at loggerheads, but in 1590 the king had commissioned Melville to write a lengthy Latin poem celebrating the coronation of his new queen: Melville duly obliged, writing the

\footnotetext{
${ }^{26}$ For background, see Alan R. MacDonald, The Jacobean Kirk, 1567-1625: Sovereignty, Polity and Liturgy (Aldershot, 1998), chs 3-4.

${ }^{27}$ Reportarie, sig. B4v. However, this was immediately followed by a rather puzzling moment when Sussex withdrew to one side attended by two grooms who knelt before him with a basin and a jug 'repleat with sweet water wherewith the Ambassador washed: a Gentleman Sewer, with humble reverence, presenting him a fair Towall, wherewith he dried his hands, and so forthwith returned to his place'. One might have expected the basin, jug and towel to be used for the baptism rather than for a ritual hand-washing.

${ }^{28}$ The pageant continued in the Great Hall where the prince was knighted and presented with a bejewelled ducal crown before the heralds 'with a loud voice' proclaimed his name and titles from the windows (ibid., sig. $\mathrm{C} 1 \mathrm{r}-\mathrm{v}$ ).

${ }^{29}$ A recent study of the ceremony (as well as the building and furnishing of the chapel royal) describes it as 'a thoroughly Reformed occasion'; see Martin Ritchie, "Dour-mongers all?": the experience of worship in the early reformed Kirk, 1559-1617' (unpublished PhD Thesis, 2 vols, University of Edinburgh, 2017), I, pp. 51-2.
} 
300 lines of the Stephaniskion in a matter of days. ${ }^{30}$ The Natalia was not commissioned, but when a furious Francis Walsingham complained that, in picturing James as 'King of all Britain', the poem broached the taboo subject of the English succession, James refused to charge Waldegrave (an Englishman) with subversion. Instead, he informed Robert Bowes, the English ambassador in Edinburgh, that 'being descended as he was, he could not but make claim to the crown of England after the decease of her Majesty'. It may be debated whether he shared all (or any) of Melville's enthusiasm for an apocalyptic future in which Britain would play a key role in a northern European Protestant confederation aimed at destroying the antichristian church of Rome. ${ }^{31}$ Nevertheless, the poem's repeated invocations of a Scoto-Britannic future is a foretaste of the British rhetoric James himself would use after 1603:

Those who ere now were divided by the Tweed,

By the shores of the Solway Firth and by the Cheviot Hills,

The rule of Scoto-Britannic sovereignty now joins together,

United in law and within a Scoto-Britannic commonwealth

And a prince born of a Scoto-Britannic king

Calls them into a single body of Scoto-Britannic people.

To what great heights will Scoto-Britannic glory now rise

With no limits set by space and time? ${ }^{32}$

The Latin may lose something in translation, but the poem articulates a keen sense of anticipation that James's imminent accession to the throne of England would inaugurate a glorious British future.

It is not clear what exactly Melville meant by employing the compound 'Scoto-Britannic', but it may well be the first ever usage of the term, echoing the earlier neologism 'Cambro-Britannus' that the Welsh antiquary Humphrey Llwyd coined to describe himself in a book published in 1572. ${ }^{33}$ Such hyphenated identities - Scoto-, Cambro-, and even Anglo-Britannus - were used in the seventeenth century to signal loyalty both to the Stewart dynasty and to the component parts of their composite monarchy. ${ }^{34}$ While never a particularly common or popular hybrid, Melville's Scoto-Britannic riff does perhaps capture, intentionally or not, what became a widespread desire among the Scottish intelligentsia to preserve the kingdom's distinctive identity within the context of a union

\footnotetext{
30 For this and what follows, see Steven J. Reid, 'Andrew Melville and the law of kingship', in Roger A. Mason and Steven J. Reid (eds), Andrew Melville (1545-1622): Writings, Reception, and Reputation (Aldershot, 2014), pp. 47-74, at p. 62.

31 On this theme, see Arthur Williamson, 'Empire and anti-empire: Andrew Melville and British political ideology', ibid., pp. 75-100.

32 For the full text and translation, see George Buchanan: The Political Poetry, ed. and trans. Paul J. McGinnis and Arthur H. Williamson (Edinburgh, 1995), pp. 276-81.

33 See the title page of his Commentarioli Britannicae Descriptionis Fragmentum, auctore Humfredo Lhuyd, Denbyghiense, Cambro-Britanno (Cologne, 1572).

34 Philip Schwyzer, 'The age of the Cambro-Britons: hyphenated British identities in the seventeenth century', The Seventeenth Century, 33 (2018), pp. 427-39.
} 
aeque principaliter. As we shall see, however, the terminology of Britain itself militated against such equality of status and esteem.

\section{III}

It is worth pointing out, if only because it is so rarely acknowledged, that in Scotland there was little if any outright hostility to the union of 1603. It might well have been a different story had an English king ascended the Scottish throne, but as it was, Scots could and did celebrate the fact that the ancient Stewart dynasty, a line of kings stretching back into remote prehistory, had vastly expanded its native patrimony. Arguably, however, such celebrations were tempered by apprehension and anxiety. Indeed, while the publications discussed in what follows trumpet the antiquity and continuity of Scottish kingship in bullishly self-confident terms, they can also be read as symptomatic of anxiety about Scotland's future status within the union. ${ }^{35}$

Such fears were hardly allayed by the king's own expressed desire for a 'complete' or 'perfect' union that would bring Scots and English together to form something other and greater than the sum of their parts. As his oft-quoted speeches to the English parliament proclaimed, the new Britain, and James's new British subjects, would subsume ancient ethnic identities and animosities in a new and presumably unitary British kingdom and nation. ${ }^{36}$ Yet, as Conrad Russell has argued, James's 'perfect' union was, at least in the short term, not incompatible with the continued existence of separate political and legal establishments within his multiple monarchy. ${ }^{37}$ What most concerned James was the issue of an undivided succession, pre-empting the possibility of the union being dissolved, and his consequent insistence that his accession to the English throne had ipso facto created a single body politic: he would not, as he famously put it, be 'a Polygamist and husband to two wiues' ${ }^{38}$ However, for lawyerly English parliamentarians, and no doubt for their Scottish counterparts too, his use of the royal prerogative to pursue his British agenda - the minting of a new British coinage, the invention of a new British flag and, above all, the adoption of a new British title - smacked of arbitrary rule and threatened the authority of both parliament and the law.

The king's new British title, 'King of Great Britain, France and Ireland, Defender of the Faith \&c', proved a particular bone of contention in both countries, for just as English parliamentarians feared being un-Englished

\footnotetext{
35 These texts are explored more fully in Roger A. Mason, 'Certeine matters concerning the realme of Scotland: George Buchanan and Scottish self-fashioning at the union of the crowns', Scottish Historical Review, 92 (2013), pp. 38-65.

${ }^{36}$ His two key speeches of 1604 and 1607 on this theme are most accessibly printed in King James VI and I, Political Writings, ed. J. P. Sommerville (Cambridge, 1994), pp. 132-46 and 159-78.

${ }^{37}$ For what follows, see Russell, James VI and I and his English Parliaments, esp. p. $62 \mathrm{ff}$.

${ }^{38}$ King James, Political Writings, p. 136.
} 
by the name of Britain, so Scots feared being Englished by it. ${ }^{39}$ As hinted already, Britain was not for Scots a neutral geographical descriptor. On the contrary, it was loaded with connotations of English superiority that stemmed originally from Geoffrey of Monmouth's twelfth-century Historia Regum Britanniae and had become deeply embedded in the socalled British History that built on Geoffrey's work and that reached its late Tudor apotheosis in successive editions of Raphael Holinshed's Chronicles of 1577 and $1587 .{ }^{40}$ If Holinshed's text was multi-vocal, its most strident voice, William Harrison's, saw Britain in unashamedly Anglocentric terms and Scotland as a dependency of the English crown. ${ }^{41}$ Even William Camden's scholarly Britannia, first published in 1586, was met with a hostile reception in Scotland, for it did nothing to dispel the assumption - indeed, did much to promote the idea - that Britain was simply England writ large. ${ }^{42}$

Such fears of English domination, and of Scottish absorption into a greater English imperium, were not uncommon in the immediate aftermath of 1603 and, no doubt further fuelled by ill-concealed English antipathy, did nothing to promote the king's British agenda. ${ }^{43}$ Scottish apprehensions were perhaps best expressed by the otherwise rather obscure Edinburgh lawyer John Russell, who in 1604 wrote 'A Treatise of the Happie and Blissed Unioun' in which he recorded his heartfelt concern that Scotland might lose its sovereign status and be reduced simply to 'a pendicle of England'. As he put it in terms that clearly affirm the principle of union aeque principaliter:

The said unioun to be mutuall and reciproque, not the translatioun of the estait of one kingdome in ane uther, not of Scotland as subaltern to Ingland, quhilk is not unioun bot ane plaine discord, the ane to be

\footnotetext{
39 In the commons, parliamentarians such as Edwin Sandys objected to the king adopting the title King of Great Britain on the grounds that it would invalidate all laws and treaties that currently ran in the name of England. The topic generated many of the printed and unprinted pamphlets on union written in 1604. See Bruce Galloway and Brian P. Levack (eds), The Jacobean Union: Six Tracts of 1604, Scottish History Society (Edinburgh, 1985), esp. pp. xix-xx and xxx-xxxv.

${ }^{40}$ On the ambiguities of British terminology, see Alan MacColl, "The meaning of "Britain" in medieval and early modern England', Journal of British Studies, 45 (2006), pp. 248-69.

${ }^{41}$ On the background to this, see Roger A. Mason, 'Scotching the Brut: politics, history and national myth in sixteenth-century Britain', in Roger A. Mason (ed.), Scotland and England, 1286-1815 (Edinburgh, 1987), pp. 60-84. More specifically on Holinshed, see Roger A. Mason, 'Scotland', in Paulina Kewes et al. (eds), The Oxford Handbook of Holinshed's Chronicles (Oxford, 2013), pp. 64762.

${ }^{42}$ On Scottish hostility to Camden, see Arthur Williamson, Scottish National Consciousness in the Age of James VI (Edinburgh, 1979), pp. 126-9, and Roger A. Mason, 'From Buchanan to Blaeu: the politics of Scottish chorography', in Caroline Erskine and Roger A. Mason (eds), George Buchanan: Political Thought in Early Modern Britain and Europe (Aldershot, 2012), pp. 12-47, esp. pp. 41-2.

${ }^{43}$ Mutual Anglo-Scottish animosity, and James's 'wishful thinking' over a new Britain, are key themes in Wormald's writings. See n. 8 above, and perhaps especially 'O Brave New World? The Union of England and Scotland in 1603', in Smout (ed.), Anglo-Scottish Relations, pp. 13-35.
} 
principall, the uther accessor, the ane to command, the uther to obey thairby ancienne Scotland to loss hir beautie for evir! God forbid! ${ }^{44}$

If few others were quite as explicit about the potential loss of Scottish sovereignty, the union was marked by a flurry of patriotic publications that both talked up the Stewart dynasty and made determined efforts to make known, not least to an English audience, the distinctiveness of Scotland and the Scots.

Chief among these was a fascinating compendium that appeared in London in 1603 under the title Certeine Matters Concerning the Realme of Scotland. ${ }^{45}$ In fact, this was a slightly revised version of a book published by Waldegrave in Edinburgh in 1594 that followed the tripartite organisation of the original. That is, it began with a 'genealogy' of the kings of Scots from Fergus I, who had allegedly founded the kingdom in $330 \mathrm{BCE}$, through to James VI, the 108th of his direct successors. This line of kings was the backbone of a Scottish usable past that had been developed and deployed to demonstrate the kingdom's historic and continuing independence of England. Its inclusion as a signal of Scottish distinctiveness was hardly surprising, though it is rather more surprising that the version of the line of kings that appeared in the 1603 edition was heavily indebted to the king's former tutor, George Buchanan, whose Rerum Scoticarum Historia had first appeared in 1582, but had been outlawed by King James two years later because of its deeply subversive politics and cruel portrayal of James's mother Mary Queen of Scots as a murdering whore. ${ }^{46}$ Despite the toxicity of his politics, Buchanan remained a cultural colossus for educated Scots and, while often unacknowledged, his influence was widespread. Indeed, the third part of Certeine Matters is a complete translation of the topographical description of Scotland that forms Book I of his Historia. Although his authorship is never acknowledged, the True Description of the whole Cuntrie of Scotland complemented the royal genealogy in offering a detailed geographical guide to the kingdom over which the descendants of Fergus had presided for nigh on two millennia. Sandwiched between these two derivative parts of Certeine Matters, however, was something both more original and further evidence of Scottish distinctiveness. This consisted of a detailed breakdown, a 'who's who', of the Scottish landed elite, from the peerage to a long list of barons, lairds and gentlemen arranged by sheriffdom, followed by a miscellany of information relating to local administrative units, royal burghs and legal institutions. While hardly a systematic breakdown of Scotland's government, it provided important information about what was, self-evidently, an independent kingdom.

\footnotetext{
44 Printed in Galloway and Levack (eds), Jacobean Union, pp. 75-142 (quotes from pp. 97, 84). For more on Russell, see Brian P. Levack, 'Law, sovereignty and the union', in Mason (ed.), Scots and Britons, pp. 213-37.

45 STC 18017; the 1594 version is STC 18016.

46 See Mason, 'Certeine Matters', pp. 40-1, 46-7.
} 
In addition to Certeine Matters, there were other publications that appeared at the time of the union that proclaimed the Scottish kingdom's antiquity and, by implication, independent sovereign status. In 1602, Andrew Melville's colleague at St Mary's College St Andrews, John Johnston, published in Amsterdam his Inscriptiones Historicae Regum Scotorum. ${ }^{47}$ This consisted of a set of elegant neo-Latin verses memorialising (and moralising on) the lives of each and every one of the long roll of Scottish kings, beginning with Fergus I and ending with James VI, and including his son and presumed successor, Prince Henry. Johnston followed Buchanan's king-list, but with one exception that would no doubt have pleased his source immensely. While Mary Queen of Scots is included in the roll, she is unenumerated, appearing numberless between her father James V, the 106th king of Scots, and her son, James VI, the 107th. That aside, the Inscriptiones is notable particularly for the series of nine engraved portraits of the Stewart monarchs from Robert II through to James VI, including Mary, and a tenth one of Anne of Denmark. Not surprisingly, Johnston's book was reissued in a postunion edition, but the portraits developed a life of their own outside the Inscriptiones. In 1602 the Edinburgh bookseller Andro Hart arranged for the printing in Amsterdam of a brief pamphlet entitled Vera Descriptio Augustissimae Stewartorum Familiae featuring the ten engravings with brief Latin descriptions of those portrayed in them. ${ }^{48}$ The image of James himself, however, was new and he was now portrayed as both much more mature and much more martial, wearing full body armour. The same image also featured in A Trew Description of the Nobill Race of the Stewards, again printed in Amsterdam, this time with vernacular descriptions of each of the Stewarts accompanying their portraits. ${ }^{49}$ This was reissued in 1603 with the addition of a cartouche to the portrait of James VI quartering the Scottish and English royal arms with an additional sentence added to the caption below: 'He is now presentlie King of England, Scotland, France and Irland, and this yeir 1603 is the first of his reigne in England \&c and the 37 yeir of his reigne in Scotland'. ${ }^{50}$

This does not exhaust the range of publications prompted by the events of 1603 that were aimed at flattering the Stewart dynasty and/or offering information about their historic kingdom. As we shall see in a moment, Thomas Craig also contributed to the flood of commendatory verses. In addition, Fowler's account of Henry's baptism, the True Reportarie, was reissued, while, much more famously, multiple editions of James's

\footnotetext{
${ }^{47}$ STC 14787; this, and the very rare post-union edition, are discussed in R. J. Lyall, 'The marketing of James VI and I: Scotland, England and the continental book trade', Quarendo, 32 (2002), pp. $204-17$, at p. 204.

${ }_{48}$ STC 1487.6. The complicated history of the engravings is traced in A. M. Hinds, Engraving in England in the Sixteenth and Seventeenth Centuries, II: The Reign of James I (Cambridge, 1955), pp. $49-51$ and plates $20-2$.

${ }_{49}$ STC 14787.2. Dated 1602 in the caption below the image of James.

${ }^{50}$ STC 14787.4.
} 
own Basilikon Doron came off the London presses. ${ }^{51}$ Yet, however wellinformed the English governing elite might be about their new king and his Scottish kingdom, the Scots themselves remained deeply concerned about their status within the Stewart composite monarchy. As late as 1607, the Scottish parliament, seriously alarmed at the way English parliamentarians such as Edwin Sandys appeared bent on promoting incorporating union, wrote to the king expressing grave concern that:

your Majesteis antient and native kingdome sould not be so disordourit and maid confusit by turneing of it, in place of a trew and friendlie Unioun, into a conquered and slavishe province to be governed by a Viceroy or Deputye, lyke suche of the King of Spaynes provinceis. ${ }^{52}$

Rightly or wrongly, Scots evidently viewed the Spanish monarchy's practice of appointing viceroys to represent the crown in many of its dominions as emblematic of conquest and incorporation and thus quite incompatible with a union aeque principaliter. Indeed, the term 'province' itself was taken as a form of dérogeance that belittled and effaced Scotland's true status. Three years earlier, in July 1604, the Scottish parliament had made its position very clear when nominating the commissioners who would meet with their English counterparts to further the king's plans for closer union. For then it tasked the commissioners with ensuring that any closer 'conjunction' should not 'prejudge or hurt the fundamentall lawes Ancient privileges offices and liberties of the kingdom', for any such hurt would mean that 'it culd no moir be a frie monarchie'. ${ }^{53}$ Among the thirty or so high-ranking nobles, clergy and officers of state who were nominated to the commission, and helped draw up the Instrument of Union later that year, was 'Master Thomas Craig, Lawyer'. ${ }^{54}$

\section{IV}

By the time of the union of 1603 , Craig had been a practising and highly successful advocate for forty years. ${ }^{55}$ Although he never held high office (he appears to have declined elevation to the bench as a Lord of Session), he was greatly esteemed for his humanist learning as well

\footnotetext{
51 On the reception of the king's political writings in England, see Jenny Wormald, 'James VI and I, Basilikon Doron and The Trew Law of Free Monarchies: the Scottish context and the English translations', in Linda Levy Peck (ed.), The Mental World of the Jacobean Court (Cambridge, 1991), pp. 36-54. As she points out (pp. 51-2), while bestsellers, they were probably more widely circulated than read, perhaps treated as 'the equivalent of a coronation mug'.

52 J. H. Burton et al. (eds), The Register of the Privy Council of Scotland, 1545-1625, 1st ser. (Edinburgh, 1877-98), VII, pp. 535-6.

53 The Records of the Parliaments of Scotland to 1707, ed. K. M. Brown et al. (St Andrews, 200714), <https://www.rps.ac.uk/1604/4/20); on the background to the Scots' apprehensions over the commission, see Galloway, Union, pp. 23-5.

${ }^{54} \mathrm{On}$ the composition and work of the commission, and the limited agenda it addressed, see Galloway, Union, pp. 62-76.

55 There is no modern biography but see John Cairns, 'Craig, Thomas (1538?-1608), lawyer and jurist', Oxford Dictionary of National Biography [accessed 28 Jan. 2020].
} 
as his legal experience. He was educated at St Andrews and Paris, and his earliest published writings were deeply patriotic neo-Latin poems celebrating the marriage of Mary of Queen of Scots to Lord Darnley in 1565 and the birth of James VI the following year. ${ }^{56}$ His enthusiasm for such formal poetic effusions never left him and, in 1603, he contributed no less than three substantial Latin poems to the outpouring of printed celebratory verse already noted: one of 425 lines saying farewell to James as he headed south in 1603, another of 409 lines on the same theme addressed to Prince Henry, and a third of 530 lines celebrating James's coronation at Westminster. While all were thoroughly patriotic, they were all also celebrations of a dynastic union that promised peace and prosperity across the Stewart monarch's three kingdoms and other farflung dominions. ${ }^{57}$ In addition to such occasional verse, however, Craig also wrote a series of four substantial prose works around the time of the union, none of which was published in his lifetime, but all of which bore witness to his remarkable legal scholarship as well as his profound concern for the future of Britain.

In terms of the academic study of law, the most important of these works was Jus Feudale, a systematic reappraisal of Scots law in a comparative European framework that followed the pioneering French humanist school of jurists in its sophisticated approach to the historical development of European law codes. ${ }^{58}$ As John Pocock argued long ago, Craig's understanding of medieval feudal law, and its significance in shaping land tenure and property rights in both Scotland and England, while a potentially powerful argument for the union of the two countries' legal systems, flew in the face of contemporary understanding of the immemorial nature and unique characteristics of English common law. ${ }^{59}$ Nonetheless, it was an argument to which Craig would return in another treatise that we will consider in a moment. Meanwhile, it is worth noting that, while his historicist approach to the development of law was heavily indebted to the French Protestant jurist François Hotman, he did not share Hotman's radical political ideas. ${ }^{60}$ Indeed, to return to our starting

\footnotetext{
56 The Epithalamium for Mary and Henry is STC 5970; the Genethliacon for James was not printed at the time, but can be found in the great miscellany of Scots neo-Latin verse, the Delitiae Poetarum Scotorum (Amsterdam,1637); the text and a translation are available through the AHRC project 'Bridging the Continental Divide: Neo-Latin and its cultural role in Jacobean Scotland, as seen in the Delitiae Poetarum Scotorum (1637)', <https://dps.gla.ac.uk/delitiae/poems/?aid=CraT $>$.

57 Respectively STC 5968, 5969 and 5971; texts and translations of all three are available at $<$ https: //dps.gla.ac.uk/delitiae/poems/?aid=CraT $>$.

58 Probably written between 1600 and 1606, it was well enough known in Scottish legal circles for efforts to be made to publish it following Craig's death in 1608 . These came to nothing and it first appeared in print in 1655. On Craig's legal scholarship, see John Cairns, David Fergus and Hector MacQueen, 'Legal humanism and the history of Scots law: John Skene and Thomas Craig', in John MacQueen (ed.), Humanism in Renaissance Scotland (Edinburgh, 1990), pp. 48-74; his political and legal thinking is explored in more detail in Glenn Burgess, British Political Thought, 1500-1660 (Basingstoke, 2009), pp. 153ff.

59 J. G. A. Pocock, The Ancient Constitution and the Feudal Law (Cambridge, 1957), ch. 4.

60 In his Francogallia (Geneva, 1573), Hotman had deployed his considerable historical and legal scholarship to demonstrate that the French monarchy was limited and accountable to the people.
} 
point, in 1602 Craig somewhat belatedly responded to the arguments of Parson's 1595 Conference about the Next Succession with a substantial treatise entitled (in its later English translation) The Right of Succession to the Kingdome of England, in Two Books. ${ }^{61}$ In Book I of this hefty tome Craig took issue with Parson's view that the kingship of England was elective by writing an extensive defence of hereditary monarchy as instituted by God in terms that echoed and amplified the king's terse statement of his divine right to rule in the True Law of Free Monarchies. No doubt James VI, to whom the book was dedicated, was delighted to see the arguments of the 'monarchomachs', not just Parsons, but the likes of Hotman and his own former tutor George Buchanan, refuted at such length. ${ }^{62}$ Equally, the detailed case made in Book II that he possessed by far the strongest claim by blood to the English throne and that being of foreign birth was no impediment to his succession was no doubt music to the king's ears. ${ }^{63}$ The tract ended, fittingly, with a paraenesis exhorting England to recognise the rightful succession of James to Elizabeth's throne, but also to embrace the possibilities for peace and concord between Scotland and England that the union would bring about. $^{64}$

However, any such union had to be seen as a union of equals based on parity of status and esteem. In yet another tract, written on the eve of union, Craig drew on his historical knowledge of feudal law to address the whole issue of Scottish monarchs paying homage to their English superiors. ${ }^{65}$ Prompted by a sense of outrage that Holinshed's view of this, or more particularly the Scotophobic aspersions of William Harrison, had not been specifically answered, he devoted well over 400 pages to exposing the Englishman's 'Fooleries and Scurrilities' and

\footnotetext{
${ }^{61}$ Edinburgh University Library, MS Dc.3.48, 'De jure successionis regni Angliae, libri Duo'; the manuscript was translated by James Gatherer and published in London in 1703 as The Right of Succession to the Kingdome of England, in Two Books; against the sophisms of Parsons the Jesuite, who assum'd the Counterfeit name of Doleman; by which he endeavours to overthrow not only the Rights of Succession in Kingdoms, but also the Sacred Authority of Kings themselves.

62 On Buchanan's ideas, and relationship with James, see the introduction to George Buchanan, A Dialogue on the Law of Kingship among the Scots: A Critical Edition and Translation of George Buchanan's 'De Iure Regni Apud Scotos Dialogus', ed. Roger A. Mason and Martin S. Smith (Aldershot, 2004), esp. pp. xxxviii-xlv.

${ }^{63}$ Indeed, Craig argued that James was not foreign at all but English by virtue of his father, Henry Stewart, Lord Darnley; for this point, and a fuller analysis of the text as a whole, see Anne McLaren, 'Challenging the monarchical republic: James I's articulation of kingship', in John F. McDiarmid (ed.), The Monarchical Republic of Early Modern England (Aldershot, 2007), pp. 165-80.

${ }^{64}$ Craig, Right of Succession, pp. 411-31.

${ }^{65}$ National Library of Scotland, Adv. MS, 16.2.25, 'De hominio disputatio adversus eos qui Scotiam feudum ligium Angliae, regemque Scotorum eo nomine hominium Anglo debere asserunt'. The manuscript was translated by George Ridpath and published in London in 1695: Scotland's Soveraignty Asserted: Being a Dispute Concerning Homage, against those who maintain that Scotland is a Feu, or Fee-Liege of England, and that therefore the King of Scots owes Homage to the King of England. As its publication in 1695 suggests, the debate rumbled on throughout the seventeenth century and became especially heated in the run-up to the parliamentary union of 1707; see William Ferguson, 'Imperial crowns: a neglected facet of the background to the Treaty of Union', Scottish Historical Review, 53 (1974), pp. 22-44.
} 
to defending Scotland's historic freedom from English overlordship. Thus, in painstaking detail, Craig dismissed evidence drawn from ancient Galfridian history as entirely spurious, while challenging any evidence that Scottish monarchs had paid homage to their Anglo-Saxon or Norman counterparts. Indeed, the Norman conquest of England afforded him the opportunity to dilate once again on the perils of upsetting strict hereditary succession, while Edward I's favouring of John Balliol over Robert Bruce in the 'Great Cause' of the 1290s was likewise construed as unwarranted interference with indefeasible hereditary right.$^{66}$ For Craig, as for many contemporary Scots, the issue of homage was clearly much more than an arcane antiquarian quarrel. On the contrary, it spoke not only to the honour of both his king and his country but to Scotland's status within a future British union.

Yet, while Craig undoubtedly adhered to the view that the future success of the union of 1603 lay in both partners acknowledging it as a union aeque principaliter, he was also prepared to go to considerable lengths to appease those in England who found the idea of AngloScottish equality hard to stomach. This comes across very strongly in the final text that Craig wrote in 1605 following his experience on the union commission: De Unione Regnorum Britanniae Tractatus. ${ }^{67}$ This brought together in summary form many of the arguments developed in his previous works. Thus he extolled monarchy as the best form of government, and saw the union of the three kingdoms under a single ruler as a providential opportunity to put an end to centuries of strife and division and inaugurate an era of peace and prosperity. Throughout he forcefully defended Scotland's historic independence, while he rebutted the slurs about the Scots' lack of civility. Even so, Craig argued, what the two kingdoms had in common - including the basic principles of their law codes - far outweighed the differences between them. Craig candidly admitted that Scotland was inferior to England in terms of population and resources, but proudly asserted that, nevertheless, England's attempts at military conquest of the northern realm had always ended in failure. Any union, he concluded, must be 'consonant with the dignity of both nations' and 'the status of neither must suffer the slightest diminution'. ${ }^{68}$

For Craig, however, as for James VI and I, while union was based on parity of status and esteem, its ultimate goal was the creation of a wholly new entity: 'two bodies ... resolved into a third, whole and distinct', as he put it, 'and of such a nature that by no device or ingenuity can it be disintegrated into its former elements' ${ }^{69}$ It has been said of Craig that he 'often provides the best clues to understanding what James was getting at'. ${ }^{70}$ Seen in this light, the arguments of De Unione may have reflected the

\footnotetext{
6 Craig, Scotland's Soveraignty, pp. 259-67 (on William) and 348-96 (on Edward).

67 National Library of Scotland, Adv. MS, 25.4.3; not published until the twentieth century: ed. and trans. C. S. Terry, Scottish History Society (Edinburgh, 1909).

68 Craig, De Unione, p. 461.

69 Ibid., p. 283.

70 Russell, James VI and his English Parliaments, p. 132.
} 
king's sometimes ambiguously expressed view that the union was already 'perfect' even though far from complete. As he told the house of commons in March 1607, 'when I speake of a perfect Vnion, I meane not confusion of al things: you must not take from Scotland those particular Priuiledges that may stand as well with this Vnion'. ${ }^{71}$ Yet, if Craig is a guide to the king's intentions, more complete union was emphatically still part of the royal agenda. His remarks on the creation of a new Britain, quoted above, were made in the context of a discussion of the broad principles of a type of union that he characterised as the 'infusion or engrafting' (infusionem aut insitionem) of two kingdoms into one. Craig went on to enumerate what he called 'the eight essentials to a complete and perfect union': uniformity of religion, customs and laws, and language; common rights and a single government; the same ecclesiastical discipline; a common coinage, weights and measures; 'and, above all, the same name'. ${ }^{72}$ Much of the rest of De Unione was concerned with how these different elements of ever closer union might be achieved. Clearly, however, this was union as long-term process that posed little immediate threat to the distinctive laws and institutions of either kingdom.

Nevertheless, in the long term, if closer and more complete union was to be achieved, Craig left little doubt that this would ultimately equate to an accessory or incorporating union on England's terms. Towards the end of De Unione, in a chapter concerned with detailing the advantages for England of closer union, he spelled out in remarkably prescient detail how the regal union would in time amount to a peaceful English conquest of Scotland:

after all the union will not differ greatly from a conquest in its results. No prince born in Scotland will ever rule that country after the prince, His Majesty's son. Our kings will be Englishmen, born in England, residing in England. They will naturally prefer Englishmen as their attendants and courtiers. Even His Majesty, though a Scotsman born, is under great obligation to the English, and must discharge it by some means or other. He may be able to extend his bounty to the Scots at present in his suite. But those who succeed them will have little chance of royal favour, since Englishmen, by whom he will chiefly be surrounded and advised, will be able to influence the king to admit or reject them. It is, therefore, probable that the royal favour will be secured by the English chiefly for their own kinsmen, relations and countrymen, seeing that through them only will the way lie open to honours, public office and rewards.

As to his fellow countrymen, their future prospects within the union looked decidedly grim. For, he went on:

Every avenue will be closed to Scots save such as money can open, and our countrymen will be of little account. London will be the seat of the court and the capital of the whole island. Thence for the most part will

71 King James, Political Writings, p.162.

72 Craig, De Unione, p. 285. 
the laws that govern us proceed. If any difficulty should present itself, to London we must look for direction, and refrain from action until we learn the views of the king and his counsellors in the capital. Towards London the wealth of Scotland will flow. Voluntarily, therefore, and in the friendliest spirit, we yield to our neighbours in this union terms such as they could not have obtained save as the result of the bloodiest war and most conclusive victory. ${ }^{73}$

There is an obvious and unresolved tension in Craig's thinking between his desire for the creation of a new Britain founded on parity of status and esteem and the enlarged England that was presaged here. Perhaps this explains why the work was never published, for neither of these options would have had much purchase among his fellow Scots. Many clearly did share Craig's belief in Scotland's historic independence and in the fundamental principle of union aeque principaliter. However, if, as seems likely, they also shared his apprehensions about the future, events would make clear that they were much less sanguine than Craig appeared to be about the prospect of absorption into a greater England. As J. H. Elliott has recently reminded us, weaker components of multiple monarchies, especially those like Catalonia and Scotland with distinctive histories and deep-rooted identities, do not always see assimilation to their stronger partners as either necessary or desirable. ${ }^{74}$

\section{V}

It is notable that in 1603, while in strict constitutional terms, England and its dominions were 'accessorised' to the Stewarts' Scottish imperium, in practice the union never was seen in this way. It was Francis Bacon who, with reference to the marriage of Henry VII's daughter Margaret to James IV in 1503, had the English king opine that 'Scotland would be but an accession to England, and not England to Scotland, for that the greater would draw the less'. ${ }^{75}$ This is not just an aphorism that the quote from Craig elaborated on at some length, but it also lies at the heart of the conundrum of the Stewarts' multiple monarchy. The categories of analysis used here, incorporating union and union aeque principaliter, have their uses, but they are at opposite ends of a spectrum that allows for many complex and untidy variations in between. It was said at the outset that not much changed in 1603. While in some respects this is true, in others it is profoundly misleading. The preponderance of England within the new Stewart imperium meant that it was perfectly possible for most of its inhabitants most of the time entirely to ignore the fact that they were part of a composite monarchy - and, arguably, most historians of

73 Ibid., pp. 440-1.

74 J. H. Elliott, Scots and Catalans: Union and Disunion (New Haven and London, 2018), esp. ch. 1.

75 First published in 1622, but see Francis Bacon, The Reign of Henry VII, ed. J. R. Lumby (Cambridge, 1885), p. 189. Bacon, of course, had been heavily involved in promoting James's unionist agenda in 1603 and after and also sat on the union commission. 
England have been content to follow suit. ${ }^{76}$ The same was not the case for the Scots, who were much more aware of being ruled by an absentee king and for whom the weight of English political, cultural and above all religious norms could prove intolerable. The constitutional and religious struggles that wracked Britain and Ireland in the seventeenth century are well beyond the scope of this short article. However, they are intimately linked to successive Stewart kings' (mis-)management of their composite but strikingly asymmetric monarchy. If not much changed in 1603, not much remained the same.

\footnotetext{
${ }^{76}$ Such enthusiasm as was inspired by J. G. A. Pocock, 'British History: a plea for a new subject', Journal of Modern History, 47 (1975), pp. 601-24, seemed to peak in the 1990s and early 2000s and has probably had more lasting impact on the historiography of Ireland and Scotland than on that of England. Pocock's plea was partly prompted by the UK's entry into the then EEC in 1973, though whether its withdrawal from the EU will reinvigorate British history, or lead to any recognition of the Anglo-Scottish union as a partnership of equals, remains to be seen.
} 